${ }^{*}$ Lukes, R J, et al, Cancer Research, 1971, 31, 1755.

${ }^{9}$ Sutcliffe, S B J, et al, British Medical fournal, 1976, 2, 1343.

${ }^{10}$ Peto, R, et al, British fournal of Cancer, 1976, 34, 585.

11 Timothy, A R, et al, British fournal of Radiology. In press.

12 Ihde, D C, et al, Cancer, 1975, 36, 1585.

${ }^{13}$ Arceneau, J C, et al, New England fournal of Medicine, 1972, 287, 1119.

${ }^{4}$ Canellos, G P, et al, Lancet, 1975, 1, 947.

${ }^{15}$ Bloomfield, C D, et al, Cancer, 1976, 38, 42

${ }^{16}$ McElwain, T, et al, British fournal of Cancer, 1977, 36, 276.
17 Glatstein, E, et al, Cancer, 1969, 24, 709.

18 Bagley, G M, et al, Cancer, 1973, 31, 840.

19 Spinelli, P, British Medical fournal, 1975, 4, 554.

20 Young, R C, et al, Lancet, 1973, 1, 1339.

21 Prosnitz, L R, et al, Radiology, 1973, 107, 187.

${ }^{22}$ Kun, L E, et al, International fournal of Radiation Oncology-Biology and Physics, 1975, 1, 619.

(Accepted 21 December 1977)

\title{
Intramuscular injections of iron compounds and oncogenesis in man
}

\author{
K WEINBREN， R SALM， G GREENBERG
}

British Medical Fournal, 1978, 1, 683-685

\section{Summary and conclusions}

To evaluate the evidence for iron compounds as local carcinogens in man, histological material and clinical reports have been reviewed in seven of the eight published cases of tumours developing at the site of intramuscular injections. The microscopical appearances suggested benign lesions in two cases and a variety of tumours in the other five. In only two cases (a rhabdomyosarcoma and a fibrosarcoma) was the interval between injections and tumour development longer than six years. Of the remaining three tumours, one was considered to be a rather slowly growing haemangiopericytoma (with an interval of two years), one appeared to be a subcutaneous lymphoma with no evidence of having arisen in the gluteal muscles, and one was a pleomorphic sarcoma with a possible five-year interval. Sarcomas induced experi-

Department of Histopathology, Royal Postgraduate Medical School, London W12 0HS

$\mathrm{K}$ WEINBREN, MD, FRCPATH, professor of histopathology

Hammersmith Hospital, London W12 0HS

R SALM, MD, FRCPATH, honorary consultant histopathologist

Medicines Division, Department of Health and Social Security, London EC2A 1PP

GILLIAN GREENBERG, MB, BS, senior medical officer mentally by iron compounds differ in being less variable in type and in containing abundant iron-containing macrophages, which were negligible in these human tumours.

Although the total number of patients who have received intramuscular injections of iron compounds is not known, the present findings, in contrast to experimental work, do not support the view that such treatment carries a strong risk of tumour development.

\section{Introduction}

Injections of some iron compounds in rodents and rabbits are associated with the development of sarcoma at the injection sites. ${ }^{1-4}$ These compounds have now been in clinical use for more than 20 years, long enough for tumours to have become apparent ${ }^{5}$ if these compounds are carcinogenic in man. There have been sporadic case reports, all but one from the United Kingdom, of tumours at previous injection sites. ${ }^{6-9}$ But whereas the experimentally induced tumours have been of similar appearance, ${ }^{10}$ the human tumour types have varied considerably. We have therefore reviewed the available material and case reports to assess whether the tumours were indeed likely to have been induced by iron injections.

\section{Review of cases}

Through the kindness of clinicians and pathologists we acquired material from seven of the total of eight published cases, and further clinical details about three of the patients (table).

Summary of 8 case reports of buttock sarcomas after intramuscular iron iniections

\begin{tabular}{|c|c|c|c|c|c|c|c|c|}
\hline $\begin{array}{l}\text { Case } \\
\text { No }\end{array}$ & Source & $\begin{array}{l}\text { Patient's } \\
\text { age } \\
\text { and sex }\end{array}$ & $\begin{array}{c}\text { Compounds } \\
\text { used }\end{array}$ & $\begin{array}{l}\text { Injection } \\
\text { sites }\end{array}$ & $\begin{array}{c}\text { Interval } \\
\text { after } \\
\text { injections } \\
\text { (years) }\end{array}$ & $\begin{array}{r}\text { Original } \\
\text { diagnosis }\end{array}$ & $\begin{array}{l}\text { Opinion on } \\
\text { review }\end{array}$ & Remarks \\
\hline 1 & Robinson et al & $74 \mathrm{~F}$ & Iron dextran & Left deltoid & 4 & Undifferentiated & Chronic inflammatory & Case excluded \\
\hline 2 & MacKinnon and & $73 \mathrm{~F}$ & $\begin{array}{l}\text { Jectofer* and } \\
\text { iron } \\
\text { dextran }\end{array}$ & Buttocks & 6 & $\begin{array}{l}\text { Reticulum-cell } \\
\text { sarcoma }\end{array}$ & $\begin{array}{l}\text { Reticulum-cell } \\
\text { sarcoma }\end{array}$ & $\begin{array}{l}\text { Subcutaneous } \\
\text { lymphoma; no } \\
\text { tumour remaining }\end{array}$ \\
\hline 3 & & $25 \mathrm{~F}$ & $\begin{array}{l}\text { Iron dextran } \\
(2 \text { courses })\end{array}$ & Buttocks & 5 and 2 & $\begin{array}{l}\text { Pleomorphic } \\
\text { sarcoma }\end{array}$ & $\begin{array}{l}\text { Pleomorphic } \\
\text { sarcoma }\end{array}$ & \\
\hline 4 & & $18 \mathrm{M}$ & Jectofer & Buttock & 2 & Fibrosarcoma & $\begin{array}{l}\text { Haemangiopericytoma } \\
\text { or mesenchymal } \\
\text { chondrosarcoma }\end{array}$ & \\
\hline 5 & Greenberg" & $40 \mathrm{~F}$ & Jectofer & Not recorded & 4 & Liposarcoma & Benign myxoma of & Case excluded \\
\hline $\begin{array}{l}6 \\
7\end{array}$ & & $\begin{array}{l}35 \mathrm{~F} \\
51 \mathrm{~F}\end{array}$ & $\begin{array}{l}\text { Iron dextran } \\
\text { "Iron" }\end{array}$ & $\begin{array}{l}\text { Not recorded } \\
\text { Buttock }\end{array}$ & "Several & $\begin{array}{l}\text { Rhabdomyosarcoma } \\
\text { Chondrosarcoma }\end{array}$ & $\begin{array}{l}\text { Rhabdomyosarcoma } \\
\text { Not examined }\end{array}$ & Case excluded \\
\hline 8 & Robertson and Dick ${ }^{9}$ & $35 \mathrm{~F}$ & Iron dextran & Buttocks & $\underset{14}{\text { month }}$ & Fibrosarcoma & Fibrosarcoma & \\
\hline
\end{tabular}

*Iron sorbitol and citric acid complex. 
Case 1-A 74-year-old woman was reported to have developed an anaplastic sarcoma of the left deltoid region four years after having iron dextran injections at this site. The tumour appears to have been cured by simple excision. In our opinion, however, the 54 sections we received all showed the features of a diffuse chronic granulomatous inflammation that included a number of large multinucleate cells, similar to those occasionally seen in active repair processes ${ }^{11}$-a diagnosis supported by Willis ${ }^{14}$ and Stout. ${ }^{15}$ Moreover, the latent period is remarkably short, and a sarcoma is rarely cured by simple excision. A further report ${ }^{16}$ even casts doubt on whether the patient received iron dextran injections in the arm. We did not therefore consider this case further.

Case $2^{7}$-A 56-year-old woman who had received injections of Jectofer (iron sorbitol and citric acid complex) and iron dextran in each buttock alternately six years previously developed a reticulumcell sarcoma that appeared to involve the subcutaneous fat rather than the gluteal muscles. We examined three stained sections and agreed with the diagnosis of reticulum-cell sarcoma of subcutaneous tissue. No muscle tissue was included. At necropsy there had been no evidence of any remaining neoplastic growth, and we are therefore somewhat doubtful whether the tumour had an intramuscular origin.

Case $3^{7}$-A 25-year-old woman had received two courses of iron dextran, in each buttock alternately, five years and two years before presenting with a tumour of the right buttock, which was diagnosed as a pleomorphic sarcoma. Radiotherapy produced little response but the patient was still free from metastases a year later. We examined six stained sections. They showed much cytological and nuclear variation and a dense reticulin network. There were no features suggesting a myosarcoma, chondrosarcoma, or liposarcoma, and we agreed with the diagnosis of pleomorphic sarcoma, even though this does not often remain stationary for as long as a year. An incubation period of either two or five years is much shorter than that of sarcomas with known incubation periods, such as postirradiation sarcomas of bone and soft tissues.

Case $4^{8}$-An 18-year-old man developed a tumour in the buttock two years after a series of Jectofer (iron sorbitol and citric acid complex) injections, presumably in the buttock or buttocks though the site was not specified. We could obtain only a single stained section. The histological appearance was unusual, crowded small, round, or elongated cells, with variable nuclei and scanty cytoplasm, being separated by wide vascular channels lined with endothelial cells (see figure). These features suggested a haemangiopericytoma; but we could not exclude the possibility of a mesenchymal chondrosarcoma, ${ }^{11} 12$ though the section we examined did not show chondroid differentiation. The features seemed most unlikely to be due to any other type of neoplasm-certainly not a rapidly growing fibrosarcoma, as originally diagnosed. Both haemangiopericytomas and chondrosarcomas grow slowly, and the tumour may therefore have been present when the patient was having the intramuscular injections of Jectofer. Young men rarely need intramuscular injections of iron compounds, and there is no evidence that he had any other condition that might have caused severe chronic iron-deficiency anaemia.

Case $5^{8}$-On checking the records of this 40-year-old woman we found that the tumour had arisen not in the buttock but in front of her thigh, abutting on the rectus sheath. She had no history of injections

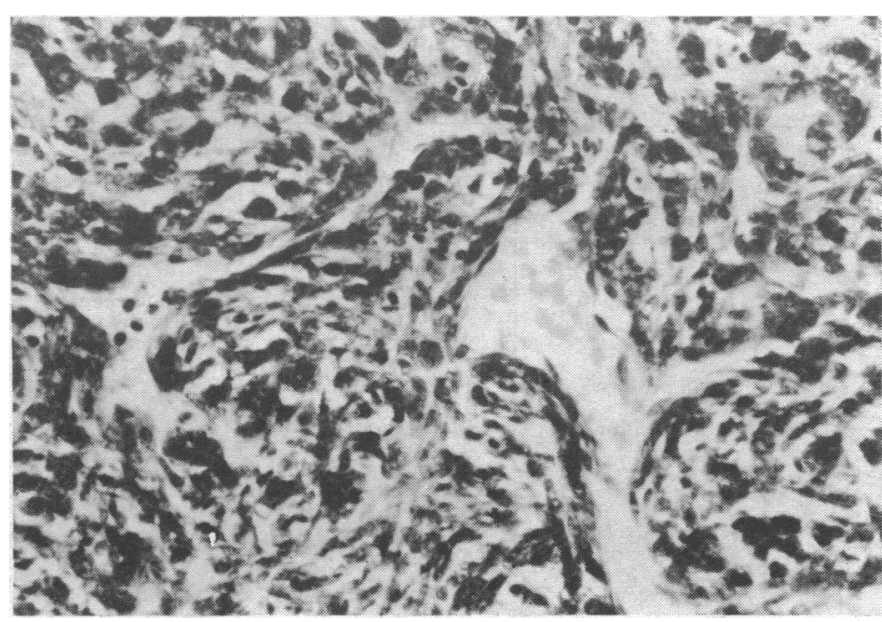

Case 4. Round and elongated cells separated by wide vascular channels, suggesting haemangiopericytoma. ( $\mathrm{H}$ and $\mathrm{E} . \times 410$.) at this site. Moreover, in our opinion the tumour was a benign intramuscular myxoma. In the six stained sections and four paraffin blocks we examined the mucoid stroma contained only sparse stellate cells; and the absence of any crowding, lipoblasts, or abundant small vessels made the diagnosis of a malignant tumour untenable.

Case $6^{8}$-A 35 -year-old woman developed a tumour in the right buttock 13 years after receiving iron dextran injections at unspecified sites. We examined 10 sections and six paraffin blocks, and agreed 0 with the original diagnosis of rhabdomyosarcoma.

Case $7^{8}$-The interval of only a few months between injections and $\overrightarrow{\overrightarrow{\vec{D}}}$ tumour development makes this lesion irrelevant. For this reason we did not ask for any material and excluded the case from further consideration.

Case $8^{9}$-A 35 -year-old woman developed a tumour in the left $\frac{\bar{D}}{\partial}$

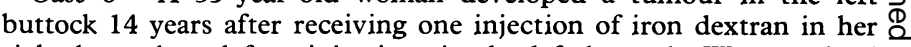
right buttock and four injections in the left buttock. We examined پ four stained sections and agreed with the original diagnosis of fibrosarcoma.

\section{Discussion}

Having eliminated three of the published cases, we are left with five tumours affecting the buttocks that developed at varying intervals after intramuscular injections of iron com- $\vec{P}$ pounds at this site. We have reservations about case 2 , however, $\dot{\circ}$ as the tumour (a lymphoma) appeared to arise from the subcutis $\omega$ rather than the gluteal muscles and is perhaps unlikely to have $\frac{\text { ? }}{2}$ been caused by the iron injections. In case 4 , moreover, there $\vec{\infty}$ was too short an interval-only two years-between the injec- $\infty$ tions and the appearance of what we considered to have been a slowly growing tumour. Indeed, in only two cases (6 and 8) were there latent periods near the range of $15-20$ years that is $\overrightarrow{0}$ expected for sarcoma induction, ${ }^{17}$ though five and six years (cases 3 and 2) should probably be considered within the possible incubation period.

How plausible then is a cause-and-effect relationship in the three remaining cases? Local sarcomas can be induced by repeated injections of iron compounds in some animal species $\stackrel{2}{\circ}$ -mice, rats, golden and Chinese hamsters, and rabbits, ${ }^{18}$ with $\stackrel{\mathbb{Q}}{\varrho}$ considerable variation in species susceptibility, ${ }^{219}$ but not $\overrightarrow{\vec{O}}$ guinea-pigs ${ }^{19}$ or squirrel monkeys. ${ }^{10}{ }^{20}$ The tumours have been $\exists$ fairly uniform, being interpreted as either fibrosarcomas or $\bar{P}$ histiocytic sarcomas. In the cases we have reviewed, however, we could find no common histological pattern; we diagnosed them as pleomorphic sarcoma, rhabdomyosarcoma, fibrosarcoma, and (if cases 2 and 4 are included) reticulum-cell sarcoma and either haemangiopericytoma or mesenchymal 3 chondrosarcoma. Moreover, there has regularly been an abundance of iron-containing macrophages in the experimental tumours ${ }^{21}$ but none in these reported tumours.

A further difference is the dose of iron compounds. The experimental tumours were induced by high doses, and the $\stackrel{N}{\sigma}$ numbers dropped sharply even when iron dextran was given at $D$ more than 50 times the clinical dose (on the basis of body weight)-in fact it sometimes produced fewer tumours than $N$ had been reported after repeated injections of glucose, fructose, arachis oil, and many other innocuous substances. ${ }^{22}{ }^{23}$ In the $\sigma$ case of a locally acting carcinogen, however, the carcinogenic dose may not vary with body weight-the molecular concen- $\frac{\text { C }}{\square}$ tration at the site may be the determining factor.

Although the clinical and experimental evidence is not conclusive a link between sarcomas of the buttock and intra- $\overline{0}$

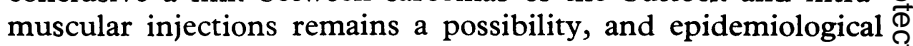
data need to be scrutinised. Before the introduction of intra- $\overrightarrow{\mathbb{D}}$ muscular iron treatment in 1954 sarcomas of the buttock showed an incidence of $6 \%{ }^{24}$ and $7 \%{ }^{25}$ of all soft-tissue sarcomas. There is so far no evidence of an increase in buttock tumours. The number of patients who have received injections of iron compounds has not been computed, and because of their wide-

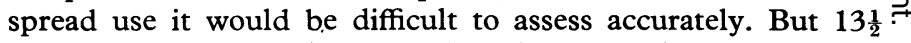
million doses were estimated to have been used in the first three years, ${ }^{26} 40$ million iron dextran injections to have been given to 3 million patients in 10 years, ${ }^{27}$ and 100 million doses to have 
been given in 14 years ( $13 \frac{1}{2}$ million of them during the first $3 \frac{1}{2}$ years). ${ }^{8}$ Thus if iron compounds had any oncogenic properties they would be expected to be apparent by now.

Nevertheless, the regular development of sarcomas in some experimental animals raises the possibility of risk to other species. As with all bioassays for carcinogenicity, until the oncogenic mechanism has been defined and unless it is found inapplicable to man, the carcinogenic potential of iron compounds cannot be entirely discounted and must be considered a hypothetical hazard of treatment. The lack of epidemiological evidence, however, suggests that it is remote.

\section{References}

${ }^{1}$ Richmond, H G, British Medical fournal, 1959, 1, 947.

2 Haddow, A, and Horning, E S, Fournal of the National Cancer Institute, 1960, 24, 109.

${ }^{3}$ Zollinger, H W, Schweizerische medizinische Wochenschrift, 1962, 92, 130.

${ }^{4}$ Roe, F J C, and Lancaster, M C, British Medical Bulletin, 1964, 20, 127.

${ }^{5}$ Haddow, A, Lancet, 1960, 2, 441.

6 Robinson, C E G, Bell, D N, and Sturdy, J H, British Medical Fournal, $1960,2,648$

' MacKinnon, A E, and Bancewicz, J, British Medical fournal, 1973, 2, 277.
${ }^{8}$ Greenberg, G, British Medical Journal, 1976, 1, 1508.

${ }^{9}$ Robertson, A G, and Dick, W C, British Medical fournal, 1977, 1, 946.

10 Carter, R L, Mitchley, B C V, and Roe, F J C, British fournal of Cancer, $1968,22,521$

${ }^{11}$ MacKenzie, D $\mathrm{H}$, The Differential Diagnosis of Fibroblastic Disorders, pp 6 and 18. Oxford, Blackwell, 1970.

12 Hedinger, C, Schweizerische medizinische Wochenschrift, 1969, 99, 1142.

${ }_{13}$ Guccion, J G, et al, Archives of Pathology, 1973, 95, 336.

14 Willis, R A, quoted by Golberg. ${ }^{22}$

${ }^{15}$ Stout, A P, quoted by Robinson et al.

${ }_{16}$ McDonald, R M, South African Medical fournal, 1960, 34, 1023.

17 Roe, F J C, in Potential Carcinogenic Hazards from Drugs, ed R Truhaut, UICC Monograph Series No 7, p 105. Berlin, Springer-Verlag, 1967.

${ }_{18}$ Haddow, A, Acta Unio Internationalis Contra Cancrum, 1963, 19, 453.

19 Haddow, A, Roe, F J C, and Mitchley, B C V, British Medical fournal, 1964, 1, 1593.

${ }^{20}$ Carter, R L, Percival, W H, and Roe, F J C, British fournal of Cancer, 1968, 22, 116

${ }^{21}$ Baker, S B de C, et al, fournal of Pathology and Bacteriology, 1961, 82, 453.

22 Golberg, L, British Medical fournal, 1960, 1, 958.

${ }^{23}$ Lanskowsky, P, South African Medical fournal, 1960, 34, 351.

${ }^{24}$ Lieberman, Z, and Ackerman, L V, Surgery, 1954, 35, 350.

${ }^{25}$ Cade, S, Proceedings of the Royal Society of Medicine, 1951, 44, 19.

${ }^{26}$ Cox, J S G, British Medical fournal, 1964, 2, 120.

27 Thedering, F, Medizinische Welt, 1964, 6, 277.

${ }^{28}$ Ballantyne, G D, Medical News, 15 December 1967.

\title{
Serum concentrations of 25 -hydroxy vitamin $D$ in Europeans and Asians after oral vitamin $D_{3}$
}

\author{
GRAHAM ELLIS, W T COOKE
}

British Medical fournal, 1978, 1, 685-686

\section{Summary and conclusions}

Serum concentrations of 25-hydroxy vitamin D (25$\mathrm{OHD}_{3}$ ) were measured in seven Asians of Indian extraction and eight Europeans before and at intervals after taking $1 \mathrm{mg}$ vitamin $D_{3}$ by mouth. In all subjects the concentrations rose in the $\mathbf{2 4}$ hours after ingestion. There was little change over the next nine days in the concentrations in the Europeans but those in the Asians continued to rise until about day 10 . Subsequent rates of fall in $25-\mathrm{OHD}_{3}$ were similar in the two groups.

Our observations suggest that the low serum concentrations of 25- $\mathrm{OHD}_{3}$ found in Asians are not caused by either impaired intestinal absorption of vitamin $D$ or rapid clearance of $25-\mathrm{OHD}_{3}$ from the plasma.

\section{Introduction}

Serum concentrations of 25-hydroxy vitamin $\mathrm{D}_{3}\left(25-\mathrm{OHD}_{3}\right)$ are lower in Asian immigrants in Britain than in the indigenous

Nutritional and Intestinal Unit, General Hospital, Birmingham B4 6NH

GRAHAM ELLIS, PHD, assistant biochemist (present address: Department of Clinical Biochemistry, Hospital For Sick Children, Toronto, Ontario M5G 1X8, Canada)

W T COOKE, MD, FRCP, honorary consultant physician and gastroenterologist white population, and although most Asians are asymptomatic, the abnormal alkaline phosphatase and parathyroid hormone concentrations suggest that many are deficient in vitamin D. ${ }^{1-4}$ Ignorance about diet has been considered to be contributory, ${ }^{2}{ }^{5}$ though abnormally low concentrations have been found in Asian hospital staff, many of whom eat the same food as their English colleagues. ${ }^{4}$ Inadequate exposure to sunshine and impaired synthesis from 7 -dehydrocholesterol in the skin on exposure to sunshine have also been suggested, though somewhat inconclusively. ${ }^{5-7}$ If skin synthesis is not the major factor and the intake of vitamin $D_{3}$ is essentially similar in whites and Asians $^{2}{ }^{4} 5{ }^{8}$ then genetic differences in vitamin-D absorption or metabolism may be responsible. We therefore measured the serum concentrations of $25-\mathrm{OHD}_{3}$ after vitamin $\mathrm{D}_{3}$ by mouth in Asian and European subjects to determine possible differences in handling.

\section{Subjects and methods}

All subjects were professional staff at this hospital. The Europeans (five men aged 19-33 years, and three women) were randomly selected from volunteers whose serum concentrations of $25-\mathrm{OHD}_{3}$ were unknown. With one exception the Asian staff (five men, two women) were invited to participate because their serum concentrations were low. ${ }^{4}$ Blood samples were taken before and at intervals after ingestion of $1 \mathrm{mg}$ vitamin $\mathrm{D}_{3}$ in $300 \mathrm{ml}$ milk one to two hours after lunch in July 1976. Fewer samples were taken from the women than the men. The subjects were asked only to avoid sunbathing and did not take holidays within six weeks after taking the vitamin D.

The initial blood samples were assessed for calcium, albumin, and alkaline phosphatase with the autoanalyser and for parathyroid hormone by the method of Addison et al. ${ }^{9}$ No abnormalities were found. $25-\mathrm{OHD}_{3}$ was measured by Ellis and Dixon's method. ${ }^{10}$ 